\title{
Relationship between CYP17 gene polymorphisms and risk of prostate cancer
}

\author{
J. Song, Z.-H. Tao, X.-Y. Liu, S. Gong and L. Gan \\ Centre for Preclinical Medicine, SiChuan Medical University, \\ Luzhou, Sichuan, China \\ Corresponding author: L. Gan \\ E-mail: luixueyi_l@163.com \\ Genet. Mol. Res. 15 (1): gmr.15017866 \\ Received October 21, 2015 \\ Accepted February 15, 2016 \\ Published February 26, 2016 \\ DOI http://dx.doi.org/10.4238/gmr.15017866
}

ABSTRACT. Cytochrome P450 17 $\alpha$-hydroxylase (CYP17) plays a critical role in androgen biosynthesis. Polymorphisms of the CYP17 promoter have been proposed as risk factors for prostate cancer; however, some studies have produced inconclusive or controversial results. We investigated the relationship between polymorphisms of the CYP17 gene and the risk of prostate cancer. A total of 176 patients with prostate cancer were enrolled in the study, and 168 healthy individuals acted as the control group. The participants were divided into those $<71$ years old and those $\geq 71$ years old. Restriction fragment length polymorphism-polymerase chain reaction was used to confirm the genotype of CYP17 in the samples. The prostate-specific antigen (PSA) concentrations were also measured in all subjects. When $\mathrm{T} / \mathrm{C}$ and $\mathrm{C} / \mathrm{C}$ were compared with $T / T$, the ORs were $0.478(P=0.489)$ and $0.814(P=0.367)$, respectively. There was no significant difference in PSA concentration among the three genotypes in the $<71$ group, whereas there were statistically significant differences in the $\geq 71$ group ( $P=0.003$ and 0.012 , respectively). There was no significant difference in free PSA and total PSA levels between the three groups and the control group. The T/C and C/C genotypes were not associated with the risk of prostate cancer, and there were no significant differences between them. In the $\geq 71$ group, the $\mathrm{T} / \mathrm{C}$ and $\mathrm{C} / \mathrm{C}$ genotypes were closely associated with 
prostate cancer, which suggests that the CYP17 gene might be a risk factor for prostate cancer in males of advanced age.

Key words: Prostate cancer; CYP17 gene; Polymorphism

\section{INTRODUCTION}

Prostate cancer is one of the most common causes of cancer-related death among men (Haider et al., 2015), and the number of cases is increasing every year. Epidemiological data indicate that prostate cancer is associated with advanced age, ethnicity, and genetic and environmental factors (Taylor et al., 1994). Further, the development and progression of prostate cancer are influenced by androgens (Ross et al., 1999). Many studies have suggested that common germ line variation in genes related to androgen biosynthesis and metabolism could alter the function of these genes and the proteins they encode, thus altering prostate cancer risk (Setiawan et al., 2007).

Genetic variation in one particular gene in this pathway, the cytochrome P450 $17 \alpha$-hydroxylase (CYP17) gene, has been studied extensively in relation to gonadal development and the synthesis of androgens and estrogens (Setiawan et al., 2007). CYP17 encodes an enzyme with both $17 \alpha$-hydroxylase and 17,20-lyase activities, the rate-limiting steps in androgen biosynthesis (Halabi et al., 2003). Recently, much attention has been focused on a number of genes coding the 5' promoter region of CYP17. The T-to-C substitution in the risk allele (A2) creates a new recognition site for the restriction enzyme MspAl, allowing the designation of wildtype (A1) and risk alleles. The polymorphism is thought to induce CYP17 gene expression resulting in higher levels of androgens and, consequently, in a higher risk of the development and progression of prostate disease (Gsur et al., 2000; Luo et al., 2012).

To assess whether there is any association between CYP17 gene polymorphisms and prostate cancer risk, we determined the frequencies and the odds ratios (ORs) of CYP17 gene polymorphisms in a case-control study that included 176 patients with histologically verified, previously untreated prostate cancer and 168 age-matched healthy people.

\section{MATERIAL AND METHODS}

\section{Subjects}

Our study included 176 patients with prostate cancer diagnosed at the Tangshan Gongren Hospital between May 2014 and May 2015. The control group comprised 168 healthy people. The mean age was 72.8 years old for the cases and 71.4 years for the controls, the median for both being 71.1 years. The study was approved by the hospital Ethics Committee, and written informed consent was obtained from all participants. The inclusion and exclusion criteria were those described in a study by Kwon et al. (2012).

\section{Polymorphism genotyping}

Blood samples were obtained from all subjects in the morning following overnight fasting. Venous blood $(5 \mathrm{~mL})$ was withdrawn using Vacutainer tubes containing ethylenediaminetetraacetic 
acid as anticoagulant. To separate plasma, blood samples were centrifuged at $3000 \mathrm{~g}$ for $10 \mathrm{~min}$. The supernatant was used for the biochemical experiments, and the buffy coat and red blood cell pellet were used for DNA extraction.

Using the method described by Carey et al. (1994), we obtained the CYP17 PCR fragment, which contains the variation, using the following primers: 5'-CATTCGCACTCTGGA-3' and 5'-GGCTCTTGGGGTAC-3'. Amplification was for 30 cycles with denaturation at $94^{\circ} \mathrm{C}$ for 1 min, annealing at $57^{\circ} \mathrm{C}$, and extension at $72^{\circ} \mathrm{C}$ for $1 \mathrm{~min}$. An initial denaturation step of $5 \mathrm{~min}$ at $94^{\circ} \mathrm{C}$ and a final extension at $72^{\circ} \mathrm{C}$ for $10 \mathrm{~min}$ were used. The PCR products were digested for 3 $\mathrm{h}$ at $37^{\circ} \mathrm{C}$ using MspAl and the resulting fragments were analyzed on 2-2.5\% agarose gels. The digested products were classified into $\mathrm{T} / \mathrm{T}, \mathrm{C} / \mathrm{C}$, and T/C genotypes.

\section{Statistical analysis}

All single nucleotide polymorphism (SNP) data were evaluated for Hardy-Weinberg equilibrium. Data are reported as median and range or means and standard deviation. Data were analyzed using the $\chi^{2}$-test and the Fisher exact test where appropriate. Differences in the frequencies of cytokine gene polymorphisms between the case and control groups were compared using logistic regression analysis. All tests were two-tailed with $95 \%$ confidence intervals. Statistical analysis was performed using the SPSS software (version 20.0). A P value $<0.05$ was considered statistically significant.

\section{RESULTS}

\section{Relationship between CYP17 gene polymorphisms and risk of prostate cancer}

The three genotypes of the CYP17 prostate cancer gene are shown in Table 1. The results showed that there was no difference in the $\mathrm{T} / \mathrm{C}$ and $\mathrm{C} / \mathrm{C}$ genotypes between the patients with prostate cancer and the control group $(P=0.489$ and 0.367 , respectively), which suggests that the $\mathrm{C}$ allele increases the risk of prostate cancer.

Table 1. Relationship between CYP17 polymorphisms and risk of prostate cancer [N (\%)].

\begin{tabular}{l|c|c|c|c|c}
\hline Genotypes & $\begin{array}{c}\text { Cases } \\
(\mathrm{N}=176)\end{array}$ & $\begin{array}{c}\text { Controls } \\
(\mathrm{N}=168)\end{array}$ & OR & $95 \% \mathrm{Cl}$ & $\mathrm{P}$ \\
\hline $\mathrm{T} / \mathrm{T}$ & $38(21.59)$ & $43(25.60)$ & 1.00 & & \\
\hline $\mathrm{T} / \mathrm{C}$ & $76(43.18)$ & $71(42.26)$ & 0.478 & $0.48-1.421$ & $0.489^{\#}$ \\
\hline $\mathrm{C} / \mathrm{C}$ & $62(35.23)$ & $54(32.14)$ & 0.814 & $0.436-1.359$ & $0.367^{\#}$ \\
\hline
\end{tabular}

${ }^{\#}$ Comparison with the $T / T$ group $(P<0.05$ considered statistically significant).

\section{Relationship between CYP17 gene polymorphisms and risk of prostate cancer in different age groups}

The samples were divided into two groups according to mean age. In the prostate cancer group, 87 cases were $<71$, and 89 cases were $\geq 71$. There was no significant difference between the three genotypes. In the $\geq 71$ group, comparing $T / C$ and $C / C$ with $T / T$, the ORs were $0.481(P=$ 0.003 ) and $0.484(P=0.012)$, respectively, which suggests that the CYP17 gene might be a risk factor for prostate cancer in males of advanced age. The results are shown in Table 2. 
Table 2. Relationship between CYP17 polymorphisms and risk of prostate cancer in different age groups.

\begin{tabular}{c|c|c|c|c|c}
\hline Genotypes & $\begin{array}{c}\text { Case group } \\
{[N(\%)]}\end{array}$ & $\begin{array}{c}\text { Control group } \\
{[N(\%)]}\end{array}$ & OR & $95 \% \mathrm{Cl}$ & $\mathrm{P}$ \\
\hline$<71$ & \multicolumn{5}{|l}{} \\
\hline $\mathrm{T} / \mathrm{T}$ & $30(17.05)$ & $23(13.69)$ & 1.00 & - & - \\
\hline $\mathrm{T} / \mathrm{C}$ & $37(21.02)$ & $38(22.62)$ & 0.657 & $0.661-2.717$ & 0.418 \\
\hline $\mathrm{C} / \mathrm{C}$ & $20(11.36)$ & $29(16.48)$ & 2.518 & $0.861-4.155$ & 0.113 \\
\hline$\geq 71$ & \multicolumn{5}{|l}{} \\
\hline $\mathrm{T} / \mathrm{T}$ & $8(4.55)$ & $21(12.5)$ & 1.00 & - & - \\
\hline $\mathrm{T} / \mathrm{C}$ & $44(25)$ & $28(16.67)$ & 0.481 & $0.094-0.622$ & $0.003^{*}$ \\
\hline $\mathrm{C} / \mathrm{C}$ & $37(21.02)$ & $29(17.26)$ & 0.484 & $0.116-0.771$ & $0.012^{*}$ \\
\hline
\end{tabular}

${ }^{*}$ Comparison with the $T / T$ group $(P<0.05$ considered statistically significant).

\section{Relationship between CYP17 polymorphism and blood PSA in the control group}

The control group was divided into three groups according to genotype, and the free prostate-specific antigen (fPSA), total PSA (tPSA), and free/total ratio (f/t) were measured. The results showed that there was no significant difference in fPSA, tPSA, and f/t between the T/C, C/C, and T/T groups, which suggests that allele A2 had no effect on the PSA level (Table 3 ).

Table 3. Relationship between CYP17 polymorphisms and prostate-specific antigen (PSA) value in the control group $(\mu \mathrm{g} / \mathrm{L})$.

\begin{tabular}{l|c|c|c|c}
\hline Genotypes & N & fPSA & tPSA & f/t \\
\hline T/T & 43 & $0.77 \pm 0.67$ & $4.52 \pm 3.98$ & $0.25 \pm 0.17$ \\
\hline T/C & 71 & $0.77 \pm 0.73$ & $4.38 \pm 4.21$ & $0.28 \pm 0.23$ \\
\hline C/C & 54 & $0.72 \pm 0.87$ & $4.68 \pm 4.72$ & $0.33 \pm 0.32$ \\
\hline
\end{tabular}

Comparison with the T/T group. fPSA $=$ free prostate-specific antigen; tPSA $=$ total prostate-specific antigen .

\section{DISCUSSION}

Oxidative stress and free radicals have been associated with the increased risk of various cancers (Goldstein and Witz, 1990; Carey et al., 1994). All higher species have evolved complex xenobiotic enzyme systems for protection against environmental genotoxins (Nebert et al., 1996). The human body has a number of endogenous free-radical scavenging systems. These include the cytochrome P-450 (CYP) enzyme, which metabolically activates pro-carcinogens to genotoxic electrophilic intermediates. Those intermediates include glutathione S-transferases, which play a central role in the inactivation of toxic and carcinogenic electrophiles (Hayes and Pulford, 1995), and paraoxonase, which principally conjugates the intermediates to excretable hydrophilic derivatives. Paraoxonase also binds to high-density lipoprotein, contributing to the detoxification of organophosphorus compounds (paraoxon) and carcinogenic lipid-soluble radicals from lipid peroxidation (Humbert et al., 1993; Shih et al., 1998). Moreover, CYP17 is well known to mediate two key steps in sex steroid synthesis, and there is accumulating evidence that endogenous levels of androgens are associated with the development of prostate cancer (Partin and Coffey, 1998). Polymorphisms in several genes are believed to be key factors in determining cancer susceptibility 
to toxic or environmental chemicals (Nebert et al., 1996; Perera, 1997). Therefore, in an effort to increase our understanding of the interaction between potential environmental exposure and genetic factors in the pathogenesis and predisposition to prostate cancer risk, we determined the frequencies and the ORs of CYP17 gene polymorphisms in a control population and in a population of patients with prostate tumors.

In this study, the results showed that there was no difference in the $\mathrm{T} / \mathrm{C}$ and $\mathrm{C} / \mathrm{C}$ genotypes between patients with prostate cancer and the control group $(P=0.489$ and 0.367 , respectively), which suggests that the $C$ allele increases the risk of prostate cancer. In the $\geq 71$ group, comparing $T / C$ and $C / C$ with $T / T$, the ORs were $0.481(P=0.003)$ and $0.484(P=0.012)$, respectively, which suggests that the CYP17 gene might be a risk factor for prostate cancer in males of advanced age. Moreover, there was no significant difference in the fPSA, tPSA, and f/t values between the T/C, $\mathrm{C} / \mathrm{C}$, and $\mathrm{T} / \mathrm{T}$ groups, which suggests that the $\mathrm{A} 2$ allele has no effect on PSA levels.

Other lines of evidence support a role for CYP17 in advanced prostate cancer. Montgomery et al. (2008) have shown that CYP17 expression is 17-fold higher in castration-resistant prostate cancer versus untreated primary tumors. Recently, two studies have evaluated SNPs within the CYP17 gene in relation to mortality in men with prostate cancer (Carey et al., 1994; Hamada et al., 2007).

Age and race are risk factors for prostate cancer. In our study, there was no significant difference in PSA concentration among the three genotypes in the $<71$ group, whereas there were statistically significant differences in the $\geq 71$ group. The results differed from some European and American countries (Yamada et al., 2001), possibly owing to racial differences.

Some potential limitations of the present study, such as the participants being Chinese Asians, may have influenced the results; hence, the inferences may not be generalized to other populations. In conclusion, the T/C and C/C genotypes were not associated with the risk of prostate cancer. In the $\geq 71$ group, the $\mathrm{T} / \mathrm{C}$ and $\mathrm{C} / \mathrm{C}$ genotypes were closely associated with prostate cancer, which suggests that the CYP17 gene might be a risk factor for prostate cancer in males of advanced age.

\section{Conflicts of interest}

The authors declare no conflict of interest.

\section{ACKNOWLEDGMENTS}

Research supported by the Sichuan Provincial Department of Education key project \#15ZA0161, and the Sichuan Medical University key projects.

\section{REFERENCES}

Carey AH, Waterworth D, Patel K, White D, et al. (1994). Polycystic ovaries and premature male pattern baldness are associated with one allele of the steroid metabolism gene CYP17. Hum. Mol. Genet. 3: 1873-1876. PubMed http://dx.doi. org $/ 10.1093 / \mathrm{hmg} / 3.10 .1873$

Goldstein BD and Witz G (1990). Free radicals and carcinogenesis. Free Radic. Res. Commun. 11: 3-10. PubMed http://dx.doi. org/10.3109/10715769009109662

Gsur A, Bernhofer G, Hinteregger S, Haidinger G, et al. (2000). A polymorphism in the CYP17 gene is associated with prostate cancer risk. Int. J. Cancer 87: 434-437. PubMed http://dx.doi.org/10.1002/1097-0215(20000801)87:3<434::AIDIJC19>3.0.CO;2-G 
Haider A, Zitzmann M, Doros G, Isbarn H, et al. (2015). Incidence of prostate cancer in hypogonadal men receiving testosterone therapy: observations from 5-year median followup of 3 registries. J. Urol. 193: 80-86. PubMed http://dx.doi.org/10.1016/j. juro.2014.06.071

Halabi S, Small EJ, Kantoff PW, Kattan MW, et al. (2003). Prognostic model for predicting survival in men with hormonerefractory metastatic prostate cancer. J. Clin. Oncol. 21: 1232-1237. PubMed http://dx.doi.org/10.1200/JC0.2003.06.100

Hamada A, Danesi R, Price DK, Sissung T, et al. (2007). Association of a CYP17 polymorphism with overall survival in Caucasian patients with androgen-independent prostate cancer. Urology 70: 217-220. PubMed http://dx.doi.org/10.1016/j. urology.2007.06.1097

Hayes JD and Pulford DJ (1995). The glutathione S-transferase supergene family: regulation of GST and the contribution of the isoenzymes to cancer chemoprotection and drug resistance. Crit. Rev. Biochem. Mol. Biol. 30: 445-600. PubMed http:// dx.doi.org/10.3109/10409239509083491

Humbert R, Adler DA, Disteche CM, Hassett C, et al. (1993). The molecular basis of the human serum paraoxonase activity polymorphism. Nat. Genet. 3: 73-76. PubMed http://dx.doi.org/10.1038/ng0193-73

Kwon SM, Cho H, Choi JH, Jee BA, et al. (2012). Perspectives of integrative cancer genomics in next generation sequencing era. Genomics Inform. 10: 69-73. PubMed http://dx.doi.org/10.5808/GI.2012.10.2.69

Luo ST, Wang YH and Xu-Kun LI (2012). Association of the CYP17 Gene T-34C Polymorphism with the Risk of Prostate Cancer: A Meta-analysis [J]. Chinese General Practice.

Montgomery RB, Mostaghel EA, Vessella R, Hess DL, et al. (2008). Maintenance of intratumoral androgens in metastatic prostate cancer: a mechanism for castration-resistant tumor growth. Cancer Res. 68: 4447-4454. PubMed http://dx.doi. org/10.1158/0008-5472.CAN-08-0249

Nebert DW, McKinnon RA and Puga A (1996). Human drug-metabolizing enzyme polymorphisms: effects on risk of toxicity and cancer. DNA Cell Biol. 15: 273-280. PubMed http://dx.doi.org/10.1089/dna.1996.15.273

Partin AW and Coffey DS (1998). The molecular biology, endocrinology, and physiology of the prostate and seminal vesicles. In: Canbell's urology. 7th edition. (Walsh PC, Retik ED, et al., eds.). Saunders WB Co., Philadelphia, 1381-1428.

Perera FP (1997). Environment and cancer: who are susceptible? Science 278: 1068-1073. PubMed http://dx.doi.org/10.1126/ science.278.5340.1068

Ross RK, Coetzee GA, Pearce CL, Reichardt JK, et al. (1999). Androgen metabolism and prostate cancer: establishing a model of genetic susceptibility. Eur. Urol. 35: 355-361. PubMed http://dx.doi.org/10.1159/000019909

Setiawan VW, Schumacher FR, Haiman CA, Stram DO, et al. (2007). CYP17 genetic variation and risk of breast and prostate cancer from the National Cancer Institute Breast and Prostate Cancer Cohort Consortium (BPC3). Cancer Epidemiol. Biomarkers Prev. 16: 2237-2246. PubMed http://dx.doi.org/10.1158/1055-9965.EPI-07-0589

Shih DM, Gu L, Xia YR, Navab M, et al. (1998). Mice lacking serum paraoxonase are susceptible to organophosphate toxicity and atherosclerosis. Nature 394: 284-287. PubMed http://dx.doi.org/10.1038/28406

Taylor JD, Holmes TM and Swanson GM (1994). Descriptive epidemiology of prostate cancer in metropolitan Detroit. Cancer 73: 1704-1707. PubMed http://dx.doi.org/10.1002/1097-0142(19940315)73:6<1704::AID-CNCR2820730625>3.0.CO;2-Y

Yamada Y, Watanabe M, Murata M, Yamanaka M, et al. (2001). Impact of genetic polymorphisms of 17-hydroxylase cytochrome P-450 (CYP17) and steroid 5alpha-reductase type II (SRD5A2) genes on prostate-cancer risk among the Japanese population. Int. J. Cancer 92: 683-686. PubMed http://dx.doi.org/10.1002/1097-0215(20010601)92:5<683::AIDIJC1255>3.0.CO:2-4 